\title{
OESTROGEN LEVELS IN PERIPHERAL BLOOD PLASMA OF THE SPOTTED SKUNK
}

\author{
RODNEY A. MEAD* AND KRISTEN B. EIK-NES \\ Division of Biochemistry and Physiology of Reproduction, Department of Physiology, \\ University of Southern California, Los Angeles, California
}

(Received 8th August 1968, revised 18th November 1968)

Western forms of the spotted skunk, Spilogale putorius latifrons, breed in late September. The fertilized oocytes undergo cleavage and blastulation but further development is greatly retarded and implantation is deferred for 180 to 200 days. Nidation occurs in mid-April and parturition takes place in mid-May (Mead, 1968). The hormonal control of delayed implantation in this species and other members of the family Mustelidae has long been a perplexing problem. Numerous investigators have suggested that delayed implantation might be the result of inadequate progesterone secretion; however, all attempts to induce nidation by injections of progesterone, have, thus far, failed (Hansson, 1947; Hammond, 1951; Canivenc \& Laffargue, 1958; Cochrane \& Shackelford, 1962; Wright, 1963). It has been conjectured that the temporary inhibition of nidation results from a negative feedback system involving increased oestrogen and reduced gonadotrophin secretion or that the high concentrations of oestrogen suppress the effects of progesterone (Hansson, 1947; Canivenc, 1966). Cochrane \& Meyer (1957) observed that progesterone is essential for maintaining viable blastocysts and that oestrogen is required to induce nidation in ovariectomized rats. Shelesnyak \& Kraicer (1963) reported that an 'oestrogen surge' which sensitizes the uterus and makes it capable of responding to decidual-inducing stimuli, is required before nidation can occur in the rat. This has led to the belief that an 'oestrogen surge' may also occur before nidation in mustelids. However, all attempts to induce nidation by injections of oestrone or oestradiol in intact or ovariectomized members of the latter family have also failed. In the light of the repeated failure of other investigators to induce nidation by injections of steroid hormones, we decided to determine the normal plasma levels of three ovarian steroids throughout the reproductive cycle. The results of the progesterone determination have been reported previously (Mead \& Eik-Nes, 1969).

The levels of free oestrone and oestradiol-17 $\beta$ in pooled peripheral plasma samples ( 15 to $30 \mathrm{ml}$ ), obtained from spotted skunks, Spilogale putorius latifrons, as previously described (Mead \& Eik-Nes, 1969), were determined by the method of Mead, Haltmeyer \& Eik-Nes (unpublished data) using gas-phase chromatography and electron capture detection. The lowest concentration of either oestrogen which can be determined by this method is about 1 nanogram (ng) per

* Present address: Department of Biological Sciences, University of Idaho, Moscow, 83843. 
sample. Peripheral plasma levels of oestrone could be quantitated in most samples throughout the year. The levels did not appear to differ significantly between pregnant and non-pregnant spotted skunks, and varied insignificantly throughout the reproductive cycle (Text-fig. 1).

Oestradiol-17 $\beta$ could only be detected in a pooled plasma sample obtained during oestrus $(3.75 \mathrm{ng} / \mathrm{ml})$, in pooled samples collected during the latter stages of pre-implantation, and throughout post-implantation (Text-fig. 1).

The gradual rise in plasma levels of oestradiol-17 $\beta$ parallelled that observed in plasma progesterone concentrations during the latter portion of pre-implantation (Mead \& Eik-Nes, 1969). During the early portion of the post-implantation period the plasma levels of both oestradiol and progesterone increased above those in pre-implantation. Plasma concentrations of the former steroid

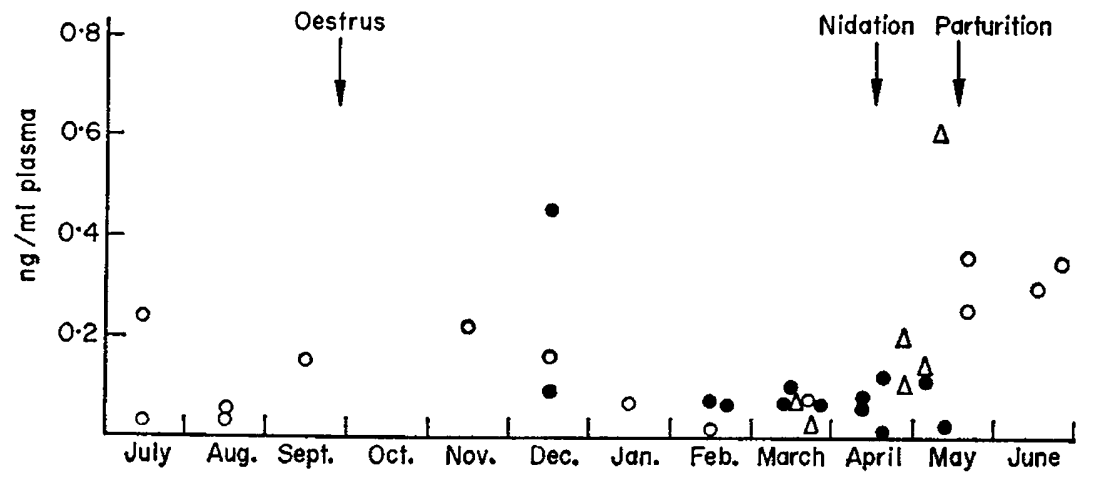

Text-Fig. 1. Plasma levels of free oestrone and oestradiol-17 $\beta$ in the spotted skunk, Spilogale putorius latifrons, throughout the reproductive cycle. $\mathrm{O}$, Oestrone (non-pregnant); , oestrone (pregnant); $\Delta$, oestradiol (pregnant). Note that oestradiol could not be detected during the early months of the pre-implantation period.

remained elevated in all post-implantation samples assayed. This rise is probably associated with mammary gland development and initiation of $\mathrm{LtH}$ secretion (Nicoll \& Meites, 1962), but vaginal cornification does not occur during pregnancy. Progesterone secretion diminished a few days after nidation and continued to fall until parturition, at which time plasma levels of this hormone were about the same as those of non-pregnant spotted skunks. Luteal cell degeneration was observed at about the midpoint of the post-implantation period.

Since plasma levels of neither oestrone nor oestradiol-1 $7 \beta$ were elevated during the early pre-implantation period, it is doubtful whether these steroids participate in preventing nidation by a negative feedback system involving hypophysial or hypothalamic regulatory centres. By the same reasoning it is unlikely that the oestrogens antagonize or suppress the effects of progesterone. Nor do our data support the theory that an 'oestrogen surge' occurs before nidation, although such data would admittedly be hard to obtain from pooled blood samples. These data suggest that increased gonadotrophin secretion occurs in the latter part of pre-implantation (February to early April) which results in a gradual rise in oestradiol-17 $\beta$ and progesterone levels. Both steroids undoubtedly play an important role in preparing the uterine environment for implantation, but may not necessarily be the factors which induce nidation in this species. If the latter 
theory is correct, it then becomes necessary to seek other mechanisms for the control of nidation as well as to elucidate factors which produce decreased gonadotrophin secretion shortly after fertilization in the spotted skunk. In view of the fact that nidation has been experimentally induced by increased photoperiods in two species of mustelids which exhibit delayed implantation (Pearson \& Enders, 1944; Wright, 1963) we suspect that the pineal gland may be involved.

This work was supported by a U.S. Public Health Service Training Grant T01 GA 5000 and by U.S. Public Health Service Research Grant AM 06651.

\section{REFERENCES}

Canivenc, R. (1966) Progestational activity in the badger (Meles meles L.). In: Egg Implantation. Ed. G. E. W. Wolstenholme. Little, Brown, Boston.

Ganivenc, R. \& Laffargue, M. (1958) Action de différents équilibres hormonaux sur la phase de vie libre de l'oeuf fécondé chez le blaireau européen Meles meles L. C.r. Séanc. Soc. Biol. 152, 58.

Cochrane, R. L. \& Meyer, R. K. (1957) Delayed nidation in the rat induced by progesterone. Proc. Soc. exp. Biol. Med. 96, 155.

Cochrane, R. L. \& Shackelford, R. M. (1962) Effects of exogenous oestrogen along and in combination with progesterone on pregnancy in the intact mink. F. Endocr. 25, 101.

Hammond, J., JR (1951) Failure of progesterone treatment to affect delayed implantation in mink. 7. Endocr. 7, 330 .

Hansson, A. (1947) The physiology of reproduction in mink (Mustela vison, Schreib.) with special reference to delayed implantation. Acta zool., Stockh. 28, 1.

MEAD, R. A. (1968) Reproduction in western forms of the spotted skunk (genus Spilogale). F. Mammal. $49,373$.

MeAd, R. A. \& Erk-Nes, K. B. (1969) Seasonal variation in plasma levels of progesterone in western forms of the spotted skunk. F. Reprod. Fert., Suppl. 6, 397.

NicolL, G. S. \& MerTes, J. (1962) Estrogen stimulation of prolactin production by rat adenohypophysis in vitro. Endocrinology, 70, 272.

Pearson, O. P. \& Enders, R. K. (1944) Duration of pregnancy in certain mustelids. 7. exp. Zool. 95, 21.

Shelesnyak, M. G. \& Kraicer, P. F. (1963) The role of estrogen in nidation. In: Delayed Implantation. Ed. A. C. Enders. University of Chicago Press.

WRIGHT, P. L. (1963) Variations in reproductive cycles in North American mustelids. In: Delayed Implantation. Ed. A. C. Enders. University of Chicago Press. 